\title{
Glycomyces sambucus sp. nov., an endophytic actinomycete isolated from the stem of Sambucus adnata Wall
}

Correspondence

Ying Huang

huangy@im.ac.cn
Qiang Gu, ${ }^{1,2}$ Wen Zheng ${ }^{1}$ and Ying Huang ${ }^{1}$

\author{
${ }^{1}$ State Key Laboratory of Microbial Resources, Institute of Microbiology, Chinese Academy of \\ Sciences, Beijing 100101, PR China \\ ${ }^{2}$ Graduate University of Chinese Academy of Sciences, Beijing 100049, PR China
}

The genus Glycomyces was initially established by Labeda et al. (1985) and the description was later emended by Labeda \& Kroppenstedt (2004). It is the type genus of the family Glycomycetaceae, which also contains the genus Stackebrandtia (Labeda \& Kroppenstedt, 2005), and belongs to the suborder Glycomycineae (Stackebrandt et al., 1997). At the time of writing, the genus comprises six species, Glycomyces algeriensis, Glycomyces arizonensis, Glycomyces harbinensis, Glycomyces lechevalierae, Glycomyces rutgersensis and Glycomyces tenuis (Labeda et al., 1985; Evtushenko et al., 1991; Labeda \& Kroppenstedt, 2004), which were all isolated from soil, and are characterized by a type II cell-wall composition (meso-diaminopimelic acid and glycine), whole-cell sugar pattern consisting of ribose, xylose, mannose and galactose, type PI phospholipids pattern with significant amounts of phosphatidylinositol mannosides, and predominant menaquinones containing 10, 11 and/or 12 isoprene units. During an investigation into the diversity of endophytic actinomycetes from Chinese medicinal plants, a new strain, $\mathrm{E} 71^{\mathrm{T}}$, was isolated. The aim of the present study was to determine the taxonomic status of this organism.

The GenBank/EMBL/DDBJ accession number for the 16S rRNA gene sequence of strain $E 71^{\top}$ is DQ460469.

A scanning electron micrograph of cells of strain $E 71^{\top}$ and tables detailing the fatty acid content and menaquinone profile of strain $E 71^{\top}$ and related species of the genus Glycomyces are available with the online version of this paper.
Stem samples of Sambucus adnata Wall, a traditional Chinese medicinal plant, were collected in the rainforest of Jinghong Natural Reserve, Yunnan Province, China, and were surface-sterilized according to the method of Coombs \& Franco (2003). Strain E71 ${ }^{\mathrm{T}}$ was isolated from the stem by using the procedure and medium described by $\mathrm{Gu}$ et al. (2006).

Genomic DNA extraction and PCR amplification of the $16 \mathrm{~S}$ rRNA gene from strain $\mathrm{E} 71^{\mathrm{T}}$ were performed according to an established method (Chun \& Goodfellow, 1995). The PCR product was purified and sequenced by using an Applied Biosystems DNA sequencer (model 3730XL) and software provided by the manufacturer. Preliminary comparison of the resultant sequence (1410 nt) against DDBJ/EMBL/GenBank databases by using a standard nucleotide-nucleotide BLAST search program (Altschul et al., 1997) indicated that strain $\mathrm{E} 71^{\mathrm{T}}$ was closely related to members of the genus Glycomyces but only very distantly related to other taxa. The 16S rRNA gene sequence of strain E71 ${ }^{\mathrm{T}}$ was then aligned with corresponding sequences of the type strains of recognized species of the genus Glycomyces retrieved from GenBank by using MEGA software (Molecular Evolutionary Genetics Analysis) version 3.1 (Kumar et al., 2004), and phylogenetic trees were constructed according to the neighbour-joining (Saitou \& Nei, 1987) and maximum-parsimony (Fitch, 1971) algorithms in the same software. Evolutionary distances for the neighbourjoining algorithm were calculated with Kimura's two-parameter model (Kimura, 1980), and close-neighbour-interchange ( search level $=2$, random additions $=100$ ) 
was applied in the maximum-parsimony analysis. The topology of the tree was evaluated by bootstrap analysis (Felsenstein, 1985) on the basis of 1000 replications. It is evident from the resultant phylogenetic tree (Fig. 1) that strain $\mathrm{E} 71^{\mathrm{T}}$ forms a distinct monophyletic line within the genus Glycomyces, supported by the two treeing algorithms and by high bootstrap values. The strain is related most closely, albeit loosely, to G. lechevalierae NRRL B- $16149^{\mathrm{T}}$, G. algeriensis NRRL B-16327 ${ }^{\mathrm{T}}$, G. harbinensis IFO14487 ${ }^{\mathrm{T}}$ and G. rutgersensis IFO14488 ${ }^{\mathrm{T}}$, with moderately low $16 \mathrm{~S}$ rRNA gene sequence similarities of $97.2-97.1 \%$, and is related more distantly to the type strains of G. arizonensis and $G$. tenuis, with sequence similarities below $96 \%$.

Cultural characteristics were observed on the media of Shirling \& Gottlieb (1966), modified Bennett's medium (Jones, 1949) and ATCC medium 172 (Cote et al., 1984). Morphological characteristics were examined by scanning electron (FEI QUANTA) microscopy of 14-day cultures grown on ISP 2 and ATCC medium 172 agar. The new organism showed cultural and morphological characteristics similar to those of G. rutgersensis, except that no pigments were produced. On most media it formed yellowish-white to tan substrate mycelium and abundant white aerial mycelia that fragmented into square-ended conidia (see Supplementary Fig. S1 available in IJSEM Online).

Biomass for chemotaxonomic study was prepared by growing the strain in shake flasks of ISP 2 at $28{ }^{\circ} \mathrm{C}$ for 7 days, and harvested by centrifugation, washed with distilled water and freeze-dried. Standard methods were used for the extraction and analysis of the isomers of diaminopimelic acid (Hasegawa et al., 1983), whole-cell sugars (Lechevalier \& Lechevalier, 1980), $\mathrm{N}$-acyl type of muramyl residue in the cell-wall peptidoglycan (Uchida et al., 1999), menaquinones (Collins, 1985), polar lipids

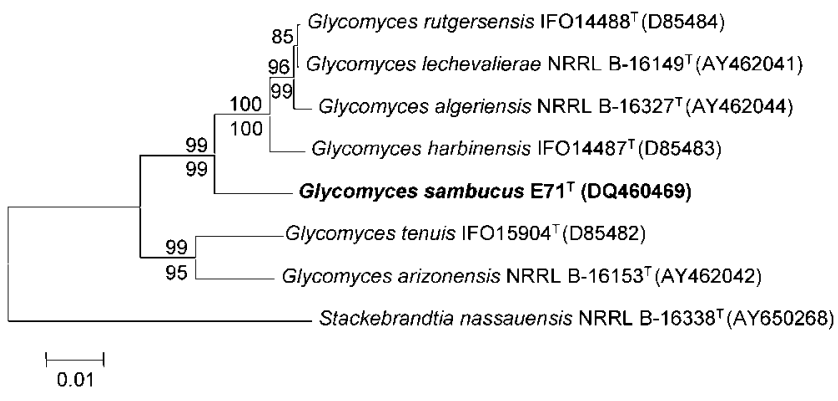

Fig. 1. Phylogenetic tree of the genus Glycomyces based on $16 \mathrm{~S}$ rRNA gene sequence analysis. The neighbour-joining and maximum-parsimony algorithms were both implemented in the software package MEGA version 3.1 (Kumar et al., 2004). Bootstrap values based on 1000 replicates are listed as percentages; those inferred from the neighbour-joining algorithm are given above branches and those from the maximum-parsimony algorithm are below. Bar, 0.01 substitutions per nucleotide position.
(Minnikin et al., 1984) and fatty acids (Sasser, 1990; Kämpfer \& Kroppenstedt, 1996). G. lechevalierae NRRL $\mathrm{B}-16149^{\mathrm{T}}$ was used as a reference. Strain $\mathrm{E} 71^{\mathrm{T}}$ showed a range of chemotaxonomic properties in line with its inclusion within the genus Glycomyces. It contained meso-diaminopimelic acid as cell-wall diamino acid; diphosphatidylglycerol, phosphatidylglycerol, phosphatidylinositol, phosphatidylinositol mannosides and several phosphoglycolipids of unknown composition as major polar lipids; a glycolyl type of muramyl acid; and its fatty acid profile was composed mainly of 15-, 16- and 17carbon iso and anteiso components. The whole-cell sugar pattern consisted of galactose, glucose, xylose and a minor amount of ribose, and was slightly different from that reported for recognized Glycomyces species (Labeda \& Kroppenstedt, 2004) in that it contained glucose but not mannose. The predominant menaquinones, which were considered to be species-specific for Glycomyces (Labeda \& Kroppenstedt, 2004), clearly differentiated strain E71 ${ }^{\mathrm{T}}$ from recognized Glycomyces species. Detailed fatty acid and menaquinone data for the new strain and related Glycomyces species are given in the formal species description below, and in Supplementary Tables S1 and S2 available in IJSEM Online. The $\mathrm{G}+\mathrm{C}$ content of the genomic DNA of strain E71 ${ }^{\mathrm{T}}$ (70 mol\%) was determined by using the thermal denaturation method (Marmur \& Doty, 1962) with Escherichia coli K12 as a control.

The physiological characteristics of strain $\mathrm{E} 71^{\mathrm{T}}$, including acid production from carbohydrates, utilization of sole carbon sources for energy and growth, and decomposition of test substances, were assessed by using the media and methods of Gordon et al. (1974). Although the results demonstrated a few common physiological characteristics among strain $E 71^{\mathrm{T}}$ and related species of the genus Glycomyces, the data enabled the new strain to be distinguished easily from the latter (Table 1). These data, together with the unique menaquinone profile, distinct position in the Glycomyces phylogenetic tree and relatively low 16S rRNA gene sequence similarities with the type strains of recognized Glycomyces species, support the designation of strain $E 71^{\mathrm{T}}$ as a novel species of the genus Glycomyces, for which the name Glycomyces sambucus sp. nov. is proposed.

\section{Description of Glycomyces sambucus sp. nov.}

Glycomyces sambucus (sam'bu.cus. N.L. gen. n. sambucus of the plant genus Sambucus)

Aerobic actinomycete that forms yellowish-white to tan substrate mycelium, depending on the growth medium. White aerial mycelia are produced and fragment into square-ended conidia. No soluble pigments are produced. Acid is not produced from L-lactulose or L-sorbose. DCellobiose, L-fucose, D-lactose, maltose, D-mannose, Drhamnose, D-sorbitol, trehalose, sucrose, glycerol, glycogen, L-arginine, L-leucine, L-ornithine, L-proline, L-tyrosine, Lvaline, methyl $\alpha$-D-glucoside and salicin are utilized as sole 
Table 1. Physiological characteristics of strain $E 71^{\top}$ and related type strains of Glycomyces species

Strains: $1, \mathrm{E} 71^{\mathrm{T}} ; 2$, G. algeriensis NRRL B-16327 ${ }^{\mathrm{T}}$; 3, G. harbinensis IFO $14487^{\mathrm{T}} ; 4$, G. lechevalierae DSM $44724^{\mathrm{T}} ; 5$, G. rutgersensis IFO $14488^{\mathrm{T}}$. +, Positive; - , negative; $\mathrm{W}$, weakly positive. All strains are positive for acid production from $\mathrm{L}$-arabinose, $\mathrm{D}$-cellobiose, dextrin, D-fructose, D-galactose, D-glucose, methyl $\alpha$-D-glucoside, glycerol Dmannose, D-rhamnose, D-xylose and salicin, for decomposition of adenine and casein, and for growth on $3 \% \mathrm{NaCl}$. All strains are negative for acid production from dulcitol, for decomposition of urea or xanthine, and for assimilation of benzoate. Data for reference strains were taken from Labeda et al. (1985) and Labeda \& Kroppenstedt (2004).

\begin{tabular}{|c|c|c|c|c|c|}
\hline Characteristic & 1 & 2 & 3 & 4 & 5 \\
\hline \multicolumn{6}{|l|}{ Acid produced from: } \\
\hline D-Lactose & + & + & + & + & $\mathrm{w}$ \\
\hline D-Mannitol & - & - & - & - & + \\
\hline D-Melezitose & - & - & - & - & $\mathrm{w}$ \\
\hline D-Raffinose & + & - & + & - & + \\
\hline D-Sorbitol & - & - & + & $\mathrm{w}$ & + \\
\hline Sucrose & + & - & - & + & - \\
\hline Trehalose & - & - & + & + & + \\
\hline Erythritol & - & - & + & - & - \\
\hline Inositol & - & + & - & + & - \\
\hline Maltose & + & $\mathrm{W}$ & + & + & + \\
\hline Methyl $\beta$-xyloside & + & - & + & - & + \\
\hline Melibiose & + & - & - & $\mathrm{w}$ & - \\
\hline Adonitol & - & - & + & + & - \\
\hline \multicolumn{6}{|l|}{$\begin{array}{l}\text { Assimilation of sole } \\
\text { carbon sources: }\end{array}$} \\
\hline Acetate & + & $\mathrm{W}$ & + & + & + \\
\hline Citrate & $\mathrm{W}$ & - & + & + & - \\
\hline Oxalate & - & $\mathrm{W}$ & - & + & - \\
\hline Succinate & + & - & + & + & - \\
\hline Malate & + & $\mathrm{W}$ & + & + & + \\
\hline Propionate & - & $\mathrm{W}$ & + & - & + \\
\hline Lactate & $\mathrm{W}$ & - & - & - & + \\
\hline Mucate & + & $\mathrm{W}$ & - & + & - \\
\hline Tartrate & + & - & - & - & - \\
\hline \multicolumn{6}{|l|}{ Decomposition of: } \\
\hline Hypoxanthine & - & - & + & + & + \\
\hline L-Tyrosine & - & - & - & + & - \\
\hline Starch & + & - & + & + & + \\
\hline Aesculin & + & - & + & + & + \\
\hline Gelatin & - & - & - & - & + \\
\hline Reduction of nitrate & $\mathrm{w}$ & $\mathrm{W}$ & w & + & + \\
\hline Growth on $5 \% \mathrm{NaCl}$ & - & + & + & + & + \\
\hline Growth at $42{ }^{\circ} \mathrm{C}$ & - & - & + & - & - \\
\hline
\end{tabular}

carbon source, but D-fructose, D-inulin, D-lactulose, D-mannitol, dulcitol, D-xylose, erythritol, inositol, L-alanine, L-methionine, L-phenylalanine, malonate, Dglutamic acid, D-sorbose and L-cysteine are not. DMelezitose and D-raffinose are weakly utilized as sole carbon source. Temperature range for growth is $20-37{ }^{\circ} \mathrm{C}$. Additional physiological properties are listed in Table 1. The whole-cell sugar pattern consists of galactose, glucose, xylose and ribose. The predominant menaquinones are MK-11 (69\%) and MK-11 $\left(\mathrm{H}_{4}\right)(26 \%)$. The fatty acid profile comprises major amounts of $16: 0$ iso $(28.8 \%)$, 15:0 anteiso $(26.2 \%)$ and $17: 0$ anteiso $(18.0 \%)$, and minor amounts of $15: 0$ iso $(8.2 \%), 14: 0$ iso $(7.2 \%), 16: 0$ iso $\mathrm{G}(5.4 \%), 17: 1$ anteiso $\mathrm{A}(2.8 \%)$ and $17: 0$ iso $(1.4 \%)$. The $\mathrm{G}+\mathrm{C}$ content of the genomic DNA is $70 \mathrm{~mol} \%$. Other chemotaxonomic characteristics are typical of the genus Glycomyces.

The type strain, E71 ${ }^{\mathrm{T}}\left(=\right.$ CGMCC $4.3147^{\mathrm{T}}=$ DSM $\left.45047^{\mathrm{T}}\right)$, was isolated from the surface-sterilized stem of Sambucus adnata Wall collected in the rainforest of Jinghong Natural Reserve, Yunnan Province, China.

\section{Acknowledgements}

This work was supported by the Knowledge Innovation Project of the Chinese Academy of Sciences, and by a grant from Hisun Pharmaceutical Company. We are grateful to Professors D. P. Labeda (NRRL) and R. M. Kroppenstedt (DSMZ) for providing reference type strains, and to Professors Cheng-Lin Jiang and Li-Hua $\mathrm{Xu}$ (Yunnan University) for their help in plant sample collection.

\section{References}

Altschul, S. F., Madden, T. L., Schäffer, A. A., Zhang, J., Zhang, Z., Miller, W. \& Lipman, D. J. (1997). Gapped BLAST and PSI-BLAST: a new generation of protein database search programs. Nucleic Acids Res 25, 3389-3402.

Chun, J. \& Goodfellow, M. (1995). A phylogenic analysis of the genus Nocardia with $16 \mathrm{~S}$ rRNA gene sequences. Int J Syst Evol Microbiol 45, 240-245.

Collins, M. D. (1985). Isoprenoid quinone analysis in classification and identification. In Chemical Methods in Bacterial Systematics, pp. 267-287. Edited by M. Goodfellow \& D. E. Minnikin. London: Academic Press.

Coombs, J. T. \& Franco, C. M. M. (2003). Isolation and identification of actinobacteria from surface-sterilized wheat roots. Appl Environ Microbiol 69, 5603-5608.

Cote, R., Daggett, P.-M., Gantt, M. J., Hay, R., Jong, S.-C. \& Pienta, P. (1984). ATCC Media Handbook. Rockville, MD: American Type Culture Collection.

Evtushenko, L. I., Taptykova, S. D., Akimov, V. N., Semyonova, S. A. \& Kalakoutskii, L. V. (1991). Glycomyces tenuis sp. nov. Int J Syst Bacteriol 41, 154-157.

Felsenstein, J. (1985). Confidence limits on phylogenies: an approach using the bootstrap. Evolution 39, 783-791.

Fitch, W. M. (1971). Toward defining the course of evolution: minimum change for a specific tree topology. Syst Zool 20, 406-416.

Gordon, R. E., Barnett, D. A., Handerhan, J. E. \& Pang, C. H.-N. (1974). Nocardia coeliaca, Nocardia autotrophica, and the nocardin strain. Int J Syst Bacteriol 24, 54-63.

Gu, Q., Luo, H., Zheng, W., Liu, Z. \& Huang, Y. (2006). Pseudonocardia oroxyli sp. nov., a novel actinomycete isolated from the surfacesterilized Oroxylum indicum root. Int J Syst Evol Microbiol 56, 2193-2197.

Hasegawa, T., Takizawa, M. \& Tanida, S. (1983). A rapid analysis for chemical grouping of aerobic actinomycetes. J Gen Appl Microbiol 29, 319-322. 
Jones, K. L. (1949). Fresh isolates of actinomycetes in which the presence of sporogenous aerial mycelia is a fluctuating characteristic. J Bacteriol 57, 141-145.

Kämpfer, M. \& Kroppenstedt, R. M. (1996). Numerical analysis of fatty acid patterns of coryneform bacteria and related taxa. Can $J$ Microbiol 42, 989-1005.

Kimura, M. (1980). A simple method for estimating evolutionary rate of base substitutions through comparative studies of nucleotide sequences. J Mol Evol 16, 111-120.

Kumar, S., Tamura, K. \& Nei, M. (2004). MEGA3: integrated software for Molecular Evolutionary Genetics Analysis and sequence alignment. Brief Bioinform 5, 150-163.

Labeda, D. P. \& Kroppenstedt, R. M. (2004). Emended description of the genus Glycomyces and description of Glycomyces algeriensis sp. nov., Glycomyces arizonensis sp. nov. and Glycomyces lechevalierae sp. nov. Int J Syst Evol Microbiol 54, 2343-2346.

Labeda, D. P. \& Kroppenstedt, R. M. (2005). Stackebrandtia nassauensis gen. nov., sp. nov. and emended description of the family Glycomycetaceae. Int J Syst Evol Microbiol 55, 1687-1691.

Labeda, D. P., Testa, R. T., Lechevalier, M. P. \& Lechevalier, H. A. (1985). Glycomyces, a new genus of the Actinomycetales. Int J Syst Bacteriol 35, 417-421.

Lechevalier, H. A. \& Lechevalier, M. P. (1980). The chemotaxonomy of actinomycetes. In Actinomycete Taxonomy, Special Publication no.
6, pp. 277-284. Edited by A. Dietz \& D. W. Thayer. Arlington, VA: Society of Industrial Microbiology.

Marmur, J. \& Doty, P. (1962). Determination of the base composition of deoxyribonucleic acid from its thermal denaturation temperature. J Mol Biol 5, 109-118.

Minnikin, D. E., O’Donnell, A. G., Goodfellow, M., Alderson, G., Athalye, M., Schaal, A. \& Parlett, J. H. (1984). An integrated procedure for the extraction of bacterial isoprenoid quinones and polar lipids. J Microbiol Methods 2, 233-241.

Saitou, N. \& Nei, M. (1987). The neighbor-joining method: a new method for reconstructing phylogenetic trees. Mol Biol Evol 4, 406-425.

Sasser, M. (1990). Identification of Bacteria by Gas Chromatography of Cellular Fatty Acids, MIDI Technical Note 101. Newwark, DE: MIDI Inc.

Shirling, E. B. \& Gottlieb, D. (1966). Methods for characterization of Streptomyces species. Int J Syst Bacteriol 16, 313-340.

Stackebrandt, E., Rainey, F. A. \& Ward-Rainey, N. L. (1997). Proposal for a new hierarchic classification system, Actinobacteria classis nov. Int J Syst Bacteriol 47, 479-491.

Uchida, K., Kudo, T., Suzuki, K. \& Nakase, T. (1999). A new rapid method of glycolate test by diethyl ether extraction, which is applicable to a small amount of bacterial cells of less than one milligram. J Gen Appl Microbiol 45, 49-56. 